УДК 330.133:65.011

Аспірант Бурбан О.В.

Аспірант кафедри підприемництва, торгівлі та біржовоі діяльності

Postgraduate student of the Department of Entrepreneurship, Trade and

Stock Exchange Activity

https://orcid.org/0000-0002-6130-8397

\title{
РОЛЬ ОЦІНЮВАННЯ ВАРТОСТІ ЯК ІНСТРУМЕНТА ПІДГОТОВКИ РІШЕНЬ ДЛЯ ОБГРУНТУВАННЯ РИНКОВОЇ КАПІТАЛІЗАЦЇ̈ ПІДПРИЕМСТВА
}

\author{
Луцьький національний технічний університет
}

В даній статті, базуючись на результатах аналізу сутності основних методів оцінювання вартості підприємства, надано подальший імпульс вивченню ролі оцінювання вартості підприємства як інструмента підготовки рішень для обгрунтування його ринкової капіталізації. Шляхом хронологічного аналізу поглядів учених на трактування поняття «капіталізація» було виявлено дуалістичну природу даної економічної категорії, що походить від капітального спрямування з одної сторони, та вартісного спрямування - $з$ іншої. Систематизувавши наукові публікації вчених 3 досліджуваної проблематики, розкрито зв'язок між поняттями «капіталізація» та «ринкова капіталізація», а також «ринкова капіталізація підприємства» та «вартість підприємства». Як результат аналізу праць А. Дамодарана подано перехід від загального до конкретного рівня взаємозв'язку між ринковою капіталізацією підприємства та оцінюванням його вартості. Беручи до уваги значний рівень диференціації інструментарію оцінювання вартості підприємства, що обумовлено наявністю трьох основних підходів оцінювання (доходного, витратного та порівняльного), уточнено природу рішень стосовно обгрунтування ринкової капіталізації підприємства в межах основних методів оцінювання. В результаті аналізу підходів систематизовано сферу застосування кожного із методів, визначено основи прийняття рішення щодо росту ринкової капіталізації. Встановлено, що основою прийняття рішення щодо росту капіталізації в межах методів доходного підходу виступають різні напрями доходності (доходності майбутніх грошових потоків, доходу від інтелектуальної власності, доходності ринкових операцій та загального рівня доходності). В межах витратних методів, де спостерігається найбільше різноманіття факторів, основою $є$ : стан основних засобів (метод чистої балансової картості), унікальні об’єкти інтелектуальної власності (метод відновної вартості), процес переоцінки наявних активів та пасивів (метод скоригованої балансової картості). Основою прийняття такого рішення в межах порівняльних методів $є$ процес порівняння із компанією-аналогом (метод компаній-аналогів), або ж купівляпродаж такої компанії (метод мультиплікаторів).

Ключові слова: капіталізація, ринкова капіталізація підприємства, оцінювання вартості, методи оцінювання вартості підприємства.

\section{VALUATION ROLE AS A TOOL OF DECISION-PREPARING FOR FOUNDATION OF COMPANY MARKET CAPITALIZATION}

\author{
Lutsk National Technical University
}

In the article based on the results of analysis of the main company valuation methods essence, the further impulse to the research of the role of company valuation as a tool of foundation of its market capitalization was given. By chronological analysis of scientists" interpretation of "capitalization" concept dualistic nature of of the mentioned economic category (which comes from the capital direction on the one hand, and the value direction on another) was discovered. Having summarized scientific papers related to the mentioned topic, the connection between concepts of "capitalization" and "market capitalization", "market capitalization" and "company value" was discovered. As a result of A. Damodaran's research papers analysis there was illustrated the transition from general to specific level of connection between company market capitalization and its valuation. Taking into consideration significant level of differentiation of company valuation tool kit, which is caused by existence of three main valuation approaches (income, cost and market), the decision nature of foundation of company market capitalization within main valuation methods was clarified. Based on the result of the approaches analysis sphere of using of each method was systemized, the basis of making decision regarding market capitalization growth was defined. It was discovered that the base of decision-making regarding capitalization growth within income approach methods are different types of income (icome from future cash flow, income from intellectual property, market operations income and general income level). Within cost methods, where the most 
factor variety is observed, the base is related to: fixed assests condition (net book value method), unique objects of intellectual property (replacement value method), existing assets and liabilities revaluation process (adjusted net book value method). The base of such decision making within the market methods is comparison with a company-analogue (comparable companies valuation method) or buying-selling such kind of company (multiplier method).

Key words: capitalization, company market capitalization, valuation, company valuation methods.

Постановка проблеми у загальному вигляді та ї̈ зв'язок з важливими науковими та практичними завданнями. В сучасних умовах господарювання основними індикаторами ефективності діяльності суб'єктів господарювання виступають показники, які відображають їх перспективний стан, дозволяючи, таким чином, інвесторам об'єктивно оцінити потенційні успіхи компанії в майбутньому. Одним із таких показників виступає ринкова капіталізація компанії, важливість якої також обумовлюється стимуляцією різнопланового розвитку підприємницької діяльності, забезпечуючи тим самим можливість розширеного відтворення. Беручи до уваги розвиток теорії та практики корпоративних фінансів, однією з основних категорій яких виступає вартість підприємства, можемо стверджувати про високу актуальність дослідження ролі оцінювання вартості підприємства як інструмента підготовик рішень для обгрунтування його ринкової капіталізації.

Аналіз останніх досліджень і публікацій, в яких започатковано вирішення проблеми. Дослідженням ринкової капіталізації підприємства, а також оцінювання його вартості займалось ряд вітчизняних та зарубіжних учених. Так, дослідження процесів капіталізації підприємства детально у своїх роботах розкрили такі науковці як: Ю. Волинчук, Й. Завадський, І. Кривов’язюк, Н. Кушнір, О. Мочерний, І. Пушкарчук, Т. Осовська, Г. Хотинська, Н. Шевченко. Дослідженням концептуальних основ трактування поняття «вартість» займалися такі як О. Дейнека, О. Давидов, О. Міщенко, Д. Іванченко, А. Шишкін, Л. Пронько, Т. Яковлєва, Г. Островська, Т. Мажиріна, М. Корягін, I. Тополя. Методи оцінки вартості підприємства в межах наявних підходів розкриті у напрацюваннях О. Вівчара, В. Задерея, І. Коваля, І. Кривов'язюка, В. Куцика, а також В. Мартинюка, Г. Міокової, В. Павлова, І. Пилипенка, А. Сендеровича, І. Явтуховської. Однак, незважаючи на глибину аналізу даних явищ як окремих економічних категорій, найбільша невизначеність, пов'язана із встановленням ролі оцінювання вартості як інструмента підготовки рішень для обгрунтування ринкової капіталізації підприємства, надалі залишається невизначеною. Тому, дана проблематика все ще $є$ важливим i актуальним завданням сьогодення.

Мета статті полягає у визначенні ролі оцінювання вартості підприємства як інструмента підготовки рішень для обгрунтування його ринкової капіталізації.

Виклад основного матеріалу дослідження 3 повним обгрунтуванням отриманих наукових результатів. Задля досягнення поставленої мети надзвичайно важливо розпочати із визначення природи ринкової капіталізації. Відповідно до підходу I. Кривов’язюка, І. Пушкарчук та Ю. Волинчук, які здійснили глибокий аналіз видового спектру поняття «капіталізація», ринкова капіталізація поряд із реальною та маркетинговою, являють собою одну 3 трьох основних форм прояву капіталізації [1, с. 138-139]. Таким чином, можемо стверджувати про необхідність аналізу сутності поняття «капіталізація» як основи «ринкової капіталізації».

Узагальнення поглядів учених на трактування поняття «капіталізація» систематизуємо у таблиці 1. 
Таблиця 1

Хронологічний аналіз поглядів учених на трактування поняття «капіталізація»

\begin{tabular}{|c|c|c|c|}
\hline Автори & Трактування поняття «капіталізація» & Рік & Природа \\
\hline $\begin{array}{l}\text { Задерей В. } \\
{[2, \text { с. } 49-50]}\end{array}$ & $\begin{array}{l}\text { Теперішня цінність активу сформована } \\
\text { очікуваних доходів від нього у майбутньому }\end{array}$ & 2016 & Вартісна \\
\hline Давидов О. [3, с.15] & $\begin{array}{l}\text { 1. Процес перетворення ресурсів на капітал } \\
\text { 2. Результат функціонування підприємства, проявом } \\
\text { якого є приріст його вартості }\end{array}$ & 2012 & Вартісна \\
\hline $\begin{array}{l}\text { Пронько Л. } \\
{[4, \text { с. 389] }}\end{array}$ & $\begin{array}{l}\text { Капіталізація - вартість усіх акцій акціонерної компанії, } \\
\text { тобто це ціна, яку ринок готовий заплатити за компанію у } \\
\text { випадку її продажу }\end{array}$ & 2011 & Вартісна \\
\hline $\begin{array}{l}\text { Шевченко Н. } \\
{[5, \text { с. } 23]}\end{array}$ & $\begin{array}{l}\text { Капіталізація - ринкова вартість акціонерного капіталу } \\
\text { відкритого акціонерного товариства, акції якого публічно } \\
\text { розміщуються на фондових біржах, а товариство офіційно } \\
\text { розміщує інформацію про власну діяльність. } \\
\text { Добуток найвищого курсу (ціни) акції на загальну } \\
\text { кількість акцій, випущених відритим акціонерним } \\
\text { товариством. }\end{array}$ & 2011 & Вартісна \\
\hline $\begin{array}{l}\text { Гончаров C., } \\
\text { Кушнір H. } \\
{[6, \text { с } 156]}\end{array}$ & $\begin{array}{l}\text { Капіталізація доходу (прибутку) - витрати прибутку на } \\
\text { збільшення капіталу фірми, перетворення прибутку в } \\
\text { капітал }\end{array}$ & 2009 & Капітальна \\
\hline $\begin{array}{l}\text { Завадський Й., } \\
\text { Осовська Т., } \\
\text { Юшкевич О. } \\
{[7, \text { с. } 124]}\end{array}$ & $\begin{array}{l}\text { 1. Капіталізація - перетворення доданої вартості на } \\
\text { капітал, тобто використання іï на розширення } \\
\text { виробництва; } \\
\text { 2. Капіталізація - це процес утворення фіктивного } \\
\text { капіталу у вигляді акцій, облігацій, заставних листів } \\
\text { іпотечних банків. }\end{array}$ & 2006 & Капітальна \\
\hline Хотинська Г. [8] & $\begin{array}{l}\text { 1.Капіталізація (реальна) - збільшення реальної вартості } \\
\text { майна за рахунок спрямування прибутку на поповнення } \\
\text { оборотних } \\
\text { 2.Капіталізація (маркетингова або суб'єктивна) - } \\
\text { зростання вартості компанії за рахунок підвищення } \\
\text { вартості нематеріальних активів (ділової репутації, } \\
\text { торгової марки тощо) та переоцінки основних засобів. }\end{array}$ & 2005 & Вартісна \\
\hline $\begin{array}{l}\text { Гаврилишин Б., } \\
\text { Мочерний О. } \\
{[9]}\end{array}$ & $\begin{array}{l}\text { Розглядається як основний рейтингоутворюючий } \\
\text { показник діяльності корпорації, який дорівнює добутку } \\
\text { кількості випущених акцій на їх ринкову ціну. }\end{array}$ & 2002 & Вартісна \\
\hline Макміллан [10] & $\begin{array}{l}\text { Капіталізація - конвертація чистого нерозподіленого } \\
\text { прибутку або резервів в емітований акціонерний капітал }\end{array}$ & 2000 & Капітальна \\
\hline Розенберг Д. [11] & Капіталізація - перетворення будь-чого на капітал & 1997 & Капітальна \\
\hline
\end{tabular}

Джерело: авторська розробка на основі [2-11]

Провівши детальний аналіз підходів вчених щодо трактування поняття «капіталізація», виявлено дуалістичний характер природи даного поняття, що обумовлено поділом поглядів науковців на дві групи.

В межах першої групи поняття «капіталізація» трактується з точки зору капітальної природи, тобто в її основу покладено приріст основних видів капіталу, за рахунок доданої вартості суб'єкта господарювання (Й. Завадський, Т. Осовська, О. Юшкевич [7, с. 124]), чи прибутку (С. Гончаров, Н. Кушнір [6, с. 156]).

В основу другої групи поглядів покладено вартість компанії, вектор росту якої, залежно від трактування, визначають: підвищення вартості нематеріальних активів (ділової репутації, торгової марки тощо) та переоцінки основних засобів (Г. Хотинська [8]), очікувані майбутні доходи, зростання курсу акцій компанії (Б. Гаврилишин, О. Мочерний [9], Н. Шевченко [5, с. 23]).

Також варто підкреслити перехід від капітальної природи капіталізації до вартісної, що є яскравим підтвердженням взаємозв'язку між вартістю компанії та їі капіталізацією. 
Найбільш чіткий зв'язок між вартістю підприємства та його ринковою капіталізацією зображений у напрацюваннях А. Дамодарана, відповідно до яких, ринкова вартість компанії визначається сумою іiі ринкової капіталізації, ринкової вартості привілейованих акцій та «чистої заборгованості» компанії [12].

Розглянувши загальний рівень впливу вартості компанії на рівень іiї капіталізації, проведемо визначення ролі вартості, як інструмента підготовки рішення для підвищення ринкової капіталізації підприємства. Зазначимо, що кожен з основних методів оцінки вартості компанії дозволяє сформувати рішення про підвищення рівня капіталізації у межах сфери свого використання. Таким чином, роль зазначених методів оцінки вартості розкривається 3 точки зору сфери їх використання а також 3 точки зору вектора прийняття рішення про підвищення капіталізації обраного суб'єкта господарювання.

Систематизовані дані щодо ролі кожного із основних методів оцінки вартості підприємства (зокрема, методу дисконтованих грошових потоків (МДГП), методу капіталізації надлишкового доходу (МКНД), капіталізації доходу (МКД), методу капіталізації чистого доходу (МКЧД), методу прямої капіталізації доходу (МПКД), методу ліквідаційної вартості (МЛВ), методу чистої балансової вартості (МЧБВ), методу оцінювання чистої ринкової вартості матеріальних активів (МОЧВМА), методу вартості заміщення (MB3), методу вартості відновлення (МBВ), методу скоригованої балансової вартості (МСБВ), методу порівняння продажів (МПП), методу компаній-ангалогів (МКА) та методу мультиплікаторів) для підвищення рівня його ринкової капіталізації подамо у таблиці 2.

Таблиця 2

Роль методів оцінки вартості підприємства у прийнятті рішення щодо зростання його капіталізації

\begin{tabular}{|c|c|c|c|}
\hline $\begin{array}{c}\text { Назва } \\
\text { підходу }\end{array}$ & Метод & Сфера застосування & $\begin{array}{c}\text { Основа прийняття рішення щодо росту } \\
\text { капіталізації }\end{array}$ \\
\hline 1 & 2 & 3 & 4 \\
\hline \multirow{5}{*}{ 瓷 } & МДГП & $\begin{array}{l}\text { Підприємства, функціонування } \\
\text { яких продовжуватиметься в } \\
\text { майбутньому }\end{array}$ & $\begin{array}{l}\text { Прийняття рішення, спираючись на оцінку } \\
\text { дисконтованих майбутніх грошових } \\
\text { потоків }\end{array}$ \\
\hline & МКНД & $\begin{array}{l}\text { Спеціалізація на на оцінці } \\
\text { інтелектуальної власності }\end{array}$ & $\begin{array}{l}\text { Дозволяє прийняти рішення спираючись на } \\
\text { дані стосовно стану інтелектуальної } \\
\text { власності }\end{array}$ \\
\hline & МКД & \multirow{2}{*}{$\begin{array}{lr}\text { Підприємства } & \text { виключно } \\
\text { позитивним } & \text { рівнем }\end{array}$} & \multirow{2}{*}{$\begin{array}{l}\text { В основу прийнятого рішення покладено } \\
\text { стан } \quad \text { прибутковості } \\
\text { господарювання }\end{array}$} \\
\hline & МКЧД & & \\
\hline & МПКД & 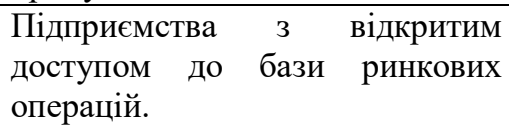 & $\begin{array}{l}\text { Прийняття рішення, спираючись на оцінку } \\
\text { проведених ринкових операцій }\end{array}$ \\
\hline \multirow{4}{*}{ 瓷 } & МЛВ & $\begin{array}{l}\text { Підприємства, які перебувають у } \\
\text { стані прискореної ліквідації }\end{array}$ & $\begin{array}{l}\text { В основу прийняття рішення покладено } \\
\text { результати оцінки підприємства в процесі } \\
\text { його ліквідації }\end{array}$ \\
\hline & МЧБВ & 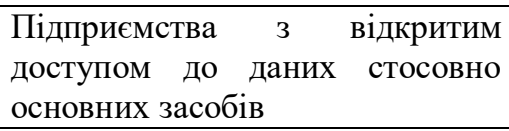 & $\begin{array}{l}\text { Прийняття рішення щодо росту } \\
\text { капіталізації відбувається на основі стану } \\
\text { основних засобів }\end{array}$ \\
\hline & МОЧРВМА & $\begin{array}{l}\text { Підприємства } 3 \text { незначною } \\
\text { часткою нематеріальних активів }\end{array}$ & $\begin{array}{l}\text { Рівень вартості матеріальних активів, } \\
\text { скоригований на показник інфляції }\end{array}$ \\
\hline & MB3 & $\begin{array}{l}\text { Підприємства } 3 \text { низькою } \\
\text { питомою вагою інтелектуальної } \\
\text { вартості }\end{array}$ & $\begin{array}{l}\text { Рішення щодо росту капіталізації } \\
\text { приймається на основі оцінки мінімальної } \\
\text { ціни, яку необхідно заплатити за } \\
\text { придбання активу аналогічної корисності } \\
\text { або аналогічної споживчої вартості }\end{array}$ \\
\hline
\end{tabular}


Продовження табл. 2

\begin{tabular}{|c|c|c|c|}
\hline 1 & 2 & 3 & 4 \\
\hline \multirow[b]{2}{*}{ : } & $\mathrm{MBB}$ & 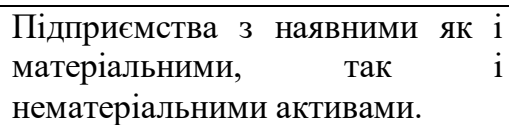 & $\begin{array}{l}\text { Формування рішення стосовно унікальних } \\
\text { об'єктів інтелектуальної власності }\end{array}$ \\
\hline & МСБВ & 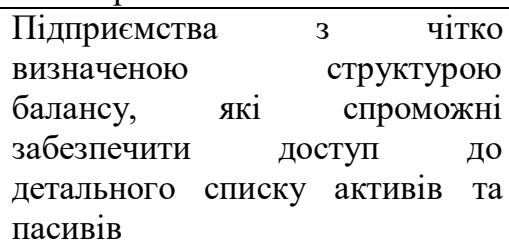 & $\begin{array}{l}\text { В основу прийняття рішення покладено } \\
\text { результати процесу переоцінювання } \\
\text { наявних активів та пасивів. }\end{array}$ \\
\hline \multirow{3}{*}{ 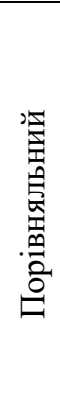 } & МПП & $\begin{array}{l}\text { Наявність інформації, щодо } \\
\text { купівлі-продажу компаній- } \\
\text { аналогів }\end{array}$ & $\begin{array}{l}\text { Дозволяє прийняти рішення, беручи до } \\
\text { уваги можливість куплів підприємства- } \\
\text { аналога або ж його контрольного пакета } \\
\text { акцій }\end{array}$ \\
\hline & MKA & $\begin{array}{l}\text { Універсальність застосування. } \\
\text { Єдиним обмеженням є наявність } \\
\text { компаній-аналогів }\end{array}$ & \multirow{2}{*}{$\begin{array}{l}\text { Основою прийняття рішення є проведення } \\
\text { фінансового аналізу аналога з визначенням } \\
\text { коефіцієнтів рентабельності й ліквідності, } \\
\text { структури капіталу, темпів росту компанії. }\end{array}$} \\
\hline & MM & $\begin{array}{l}\text { Публічні акціонерні товариства } 3 \\
\text { великими маштабами діяльності }\end{array}$ & \\
\hline
\end{tabular}

Джерело: авторська розробка на основі [2-13]

На основі проведеного аналізу, беручи до уваги ступінь вагомості методів оцінки вартісті суб'єкта господарювання у прийнятті рішення щодо нарощення його капіталізації, зазначимо, що: в межах доходного підходу основою такого рішення виступають різноманітні напрями доходності: від інтелектуальної власноті (МКНД), майбутніх грошових потоків (МДГП), від ринкових операцій (МПКД) та загального рівня доходності у розрізі методів капіталізації доходів; найбільше різноманіття факторів впливу на прийняття зазначеного рішення, помічено у розрізі витратних методів, такими факторами є: стан унікальних об'єктів інтелектуальної власності (МВВ), стан основних засобів (МЧБВ), процес переоцінки існуючих активів та пасивів (МСБВ); в межах порівняльних методів, відповідно до їх природи, основою прийняття такого рішення $є$ порівняння 3 компанією-аналогом (МКА та ММ) та факт покупки даної компанії в цілому (МПП) [14].

Висновки. Сучасні науково-методичні підходи учених до трактування поняття «капіталізація» характеризуються наявним дуалізмом щодо тлумачення його сутності, в основі чого лежить їх поділ на дві основні групи: залежно від капітальної, чи вартісної природи цільового поняття. Протягом останніх років у практиці господарювання фінансовому менеджменті компаній, управлінській діагностиці, професійній діяльності на ринку нерухомості спостерігається підвищення вагомості вартісної природи капіталізації, що яскраво ілюструє загальну взаємозалежність між вартістю підприємства та його ринковою капіталізацією (однією з трьох основних форм вияву капіталізації). Аналіз напрацювань А. Дамодарана дозволив виявити більш конкретний рівень взаємозалежності між ринковою капіталізацією та вартістю компанії, описаний прямою кореляцією даних понять.Проаналізувавши сфери застосування основних методів оцінювання вартості підприємства в розрізі трьох основних підходів (доходного, витратного та ринкового), встановлено, що роль оцінювання вартості підприємства як інструмента підготовки рішень для обгрунтування його ринкової капіталізації характеризується значною диференціацією та залежить від значення оцінювання для ринку або підприємства. Подальші розвідки планується спрямувати на практику застосування існуючих методів 3 метою оптимізації їх використання для прийняття управлінських рішень. 


\section{Список бібліографічного опису:}

1.Кривов’ язюк І.В., Пушкарчук І.М., Волинчук Ю.В. Капіталізації як основа динамічного розвитку підприємств. Економічний форум. 2017. № 1. С. 135-144.

2.Задерей В.Ю. Методи оцінки вартості компаній. Агросвіт. 2017. № 5. С. 48-54.

3.Давидов О.І. Вартість підприємства як економічна категорія. Актуальні проблеми економіки. 2014. № 5. С. 8-19.

4.Пронько Л.М. Вартість і капіталізація підприємств та методи їх оцінки. Екномічні науки. 2011. № 18. C. $384-391$.

5.Шевченко Н.В. Ринкова капіталізація акціонерних товариств: сутність, функції та проблеми управління. Економіка та держава. 2011. № 9. С. 22-24.

6.Гончаров С.М., Кушнір Н.Б. Тлумачний словник економіста. Київ : Центр учбової літератури, 2009. $264 \mathrm{c.}$

7.Завадський Й.С., Осовська Т.В., Юшкевич О.О. Економічний словник. Київ, 2006. 356 с.

8.Хотинская Г.И. Теория и практика капитализации в условиях рынка. Собственность и рынок. 2005. № 9. С. 2-5.

9. Економічна енциклопедія : У трьох томах. Т. 1. / Редкол.: С.В. Мочерний (відп. ред.). Київ : Видавничий центр «Академія», 2000. 864 с.

10. Словник сучасної економіки Макмілана / Редкол.: Девід В.Пірс (відп. ред.). Київ: Видавничий центр «АртЕк», 2000. $640 \mathrm{c}$.

11. Розенберг Д. Словарь банковских терминов. Москва : ИНФРА-М, 1997. 360 с

12. Damodaran A. Valuation: Security analysis for investments and corporate finance. Wiley Finance, 2015. $1372 \mathrm{p}$.

13. Економіка нерухомості : навч. посіб. / А.М. Асаул, В.І. Павлов, І.І. Пилипенко, Н.В. Павліха, І.В. Кривов'язюк. Київ : IВЦ Держкомстату України., 2004. 350 с.

14. Кривов'язюк I.В., Бурбан О.В. Оцінювання вартості як інструмент регулювання ринкової капіталізації суб'єктів господарювання. Економіка і менеджмент 2020: перспективи інтеграції та інноваційного розвитку : зб. наук. праць Міжнар. наук.-практ. конф., (м. Дніпро, 2-3 квітня 2020 р.). Дніпро, 2020. С. 99-101.

\section{References:}

1.Kryvovyazyuk I., Pushkarchuk I., Volynchuk Y. (2017) Kapitalizatsiyi yak osnova dynamichnoho rozvytku pidpryyemstv [Capitalizations as a basis for dynamic enterprise development]. Ekonomichnyy forum - Economic forum, 1. 135-144.

2.Zaderey V. (2017) Metody otsinky vartosti kompaniy [Companies valuation methods]. Ahrosvit - Agrosvit, 5. $48-54$.

3.Davydov O. (2014) Vartist' pidpryyemstva yak ekonomichna katehoriya [Enterprise value as an economic category]. Aktual'ni problemy ekonomiky - Actual problems of economics, 5. 8-19.

4.Pron'ko L. (2017) Vartist' i kapitalizatsiya pidpryyemstv ta metody yikh otsinky [Value and capitalization of enterprises and their valuation methods] Ahroinkom: naukovo-praktychne vydannya-Agroincom: scientific and practical publication, 12. 113-117.

5.Shevchenko N. (2011) Rynkova kapitalizatsiya aktsionernykh tovarystv: sutnist', funktsiyi ta problemy upravlinnya [Market capitalization of joint stock companies: essence, functions and problems of management]. Ekonomichna nauka. Ekonomika ta derzhava. - Economic Science. Economy and state, 9. 22-24.

6.Honcharov S., Kushnir N. (2009), Tlumachnyy slovnyk ekonomista [Explanatory dictionary of the economist]. Kyyiv: Tsentr uchbovoyi literatury, Kyiv [in Ukrainian].

7. Zavads'kyy Y., Osovs'ka T., Yushkevych O. (2006) Ekonomichnyy slovnyk [Economic dictionary]. Kyiv [in Ukrainian].

8. Khotinskaya G. (2005) Teoriya i praktika kapitalizatsii v usloviyakh rynka [Theory and practice of capitalization in market conditions]. Sobstvennost' i rynok - Property and market, 9. 2-5.

9.Mochernyy S. (2000) Ekonomichna entsyklopediya [Economic encyclopedia]. Akademiya, Kyiv [in Ukrainian].

10. Pirs D. Slovnyk suchasnoyi ekonomiky Makmilana [Macmillan's Dictionary of Modern Economics]. ArtEk, Kyiv [in Ukrainian].

11. Rozenberh D. Slovar' bankovskykh termynov [Dictionary of banking terms]. INFRA-M, Moscow [in Russian].

12. Damodaran A. (2015) Valuation: Security analysis for investments and corporate finance. WileyFinance, 1372.

13. Asaul, A. M., Pavlov, V.I., Pilipenko, I.I., Pavlikha, N.V., Kryvov’yazyuk, I.V. (2004). Ekonomikanerukhomosti: navch. posib. [Real Estate Economics: Teach. manual]. Kyiv: IVTS Derzhkomstatu Ukrayiny [in Ukrainian].

14. Kryvovyazyuk I.V., Burban O.V., Otsinyuvannya vartosti yak instrument rehulyuvannya rynkovoyi kapitalizatsiyi sub'yektiv hospodaryuvannya. Mizhnar. nauk.-prakt. konf. "Ekonomika i menedzhment 2020: perspektyvy intehratsiyi ta innovatsiynoho rozvytku : zb. nauk. Prats". Dnipro, 2020, p. 99-101 [in Ukrainian].

Дата подання публікації 30.11.2020 p. 